\title{
Insecticidal Activity of Annonaceous Acetogenins and Their Derivatives on Spodoptera frugiperda Smith (Lepidoptera: Noctuidae)
}

\author{
José Ruiz Hidalgo¹, Eduardo A. Parellada1, Alicia Bardón'1,2, Nancy Vera ${ }^{3}$, Adriana Neske1* \\ ${ }^{1}$ Instituto de Química Orgánica, Facultad de Bioquímica, Química y Farmacia, UNT, Tucumán, Argentina \\ ${ }^{2}$ Inquinoa-Conicet, Facultad de Bioquímica, Química y Farmacia, UNT, Tucumán, Argentina \\ ${ }^{3}$ Instituto de Farmacia, Facultad de Bioquímica, Química y Farmacia, UNT, Tucumán, Argentina \\ Email: joserh16@yahoo.com.ar, eapa rellada@hotmail.com, alicia.bardon@gmail.com,nrvera@fbqf.unt.edu.ar, \\ *aneske@fbqfunt.edu.ar
}

How to cite this paper: Ruiz Hidalgo, J., Parellada, E.A., Bardón, A., Vera, N. and Neske, A. (2018) Insecticidal Activity of Annonaceous Acetogenins and Their Derivatives on Spodoptera frugiperda Smith (Lepidoptera: Noctuidae). Journal of Agricultural Chemistry and Environment, 7, 105-116.

https://doi.org/10.4236/jacen.2018.73010

Received: March 16, 2018

Accepted: July 6, 2018

Published: July 9, 2018

Copyright () 2018 by authors and Scientific Research Publishing Inc. This work is licensed under the Creative Commons Attribution International License (CC BY 4.0).

http://creativecommons.org/licenses/by/4.0/

\section{(c) (i) Open Access}

\begin{abstract}
Background: Annonaceous acetogenins enclose a large number of biological activities, among which the insecticidal stands out. Methods: We report herein the biocide effects of natural acetogenins from Annona squamosa, $A$. muricata and $A$. montana seeds: annonacin, cis-annonacin, cis-annonacin-10one, asimicin, rolliniastatin-2, cherimolin-1, cherimolin-2, almuñequin, and two $\beta-\mathrm{OH}$ acetogenins: laherradurin and itrabin on Spodoptera frugiperda Smith (Lepidoptera: Noctuidae). Also, some acetylated and methoxy methylated ACG derivatives were synthesized and evaluated: annonacin ( $3 \mathrm{OAc}$ ), annonacin $(4 \mathrm{OAc})$, asimicin $(3 \mathrm{OAc})$, rolliniastatin-2 (3 OAc), rolliniastatin-2 (MOM), laherradurin (3 OAc) and itrabin (3 OAc). Results: The natural acetogenin rolliniastatin-2 $\left(100 \mu \mathrm{g} \cdot \mathrm{g}^{-1}\right.$ of diet $)$ produced the most important toxic action causing $100 \%$ mortality of early instar larvae. Derivatization of ACG yielded compounds that produced nutritional alterations. The incorporation of rolliniastatin-2 (3 OAc) and rolliniastatin-2 (3 MOM) $\left(100 \mu \mathrm{g} \cdot \mathrm{g}^{-1}\right)$ into the artificial diet of Spodoptera frugiperda displayed the strongest antifeedant effects causing marked decreasings in larval growth and adult lethal malformations. Conclusion: Natural acetogenins are promising metabolites for insect control. Derivatization of these compounds reduces their toxicity to early instar larvae.
\end{abstract}

\section{Keywords}

Annonaceous Acetogenins, Biocides, Spodoptera frugiperda 


\section{Introduction}

Given the environmental and human health problems caused by synthetic insecticides there has been an upsurging on research for plant compounds for insect control. In the last 30 years, there has been an increasing research on plant extracts [1], leading to what could be considered a second era of botanical insecticides [2]. The practice of using plant extracts for pest control in agriculture is not new; for at least two millennia, botanical insecticides were considered important products for pest management in Ancient China [3], Egypt, Greece and India [4]. Before the discovery of organochlorine and organophosphate insecticides in the late 1930's and early 1940's [4], botanical insecticides were predominantly used in the United States and some European countries.

The plants that present biological activities against insects owe this feature to the presence of secondary metabolites [5], some of which have been widely investigated [6] [7] [8].

Depending of the nature of their chemical structure, plant secondary metabolites or a mixture of them, may exert biocide action and therefore insecticidal activity [9] [10]. However, most plants used against insects have an insectistatic effect. The concept of insectistatic refers to the inhibition of the insect's development and behaviour [10], and encloses repellence [11], antifeedant activity [12], growth regulation [13], feeding deterrence [14] and oviposition deterrence [15]. Repellent plants possess fowling odor or irritating compounds which cause insects to get away from them [16]. Antifeedant activity is exerted by compounds that once ingested by insects, cause them to stop feeding and eventually die of starvation [4]. Growth regulating compounds inhibit metamorphosis or provoke precocious molting. They alter the growth regulating hormones and cause malformations, sterility or death of insects [10].

Biological activity of secondary metabolites has proven to be higher when using plant extracts, but since most investigations have consisted of in vitro assays for insecticidal activity, their field effectiveness is yet unknown [17].

Acetogenins from the Annonaceae family (ACG) had drawn a lot of attention since the 1980's since they feature a variety of structural characteristics and biological activities [18].

ACG enclose a series of natural products derived from C-32/C-34 fatty acids combined with a 2-propanol unit [19]. They are found in leaves, branches and mostly in seeds of annonaceous plants. Certain ACG were shown to block $\mathrm{NADH}$ ubiquinone reductase (Complex I) of the respiratory chain, directly affecting the electron transport in the mitochondria, causing ATP levels to decrease and cells to undergo apoptosis [19]. The annonaceous extracts have been evaluated in several groups of insects of both medical (Aedes aegypti L., mosquito, dengue fever and yellow fever vector in tropical areas [22] [23]) and agricultural importance (chewing-insects like Lepidoptera larvae [6] [20] and sap-sucking species like Myzus persicae S. [21]).

The insecticidal properties of ACG isolated from the Annona genus against 
several key crop pests in different parts of the world have repeatedly been described [6] [24] [25] [26].

In this study, chloroform extracts from Annona squamosa, $A$. muricata and $A$. montana seeds were prepared and ACG isolated from them. Then, acetylated $(\mathrm{OAc})$ and methoxy methylated (MOM) derivatives were synthesized, purified by chromatographic techniques and characterized by spectroscopic techniques (RI, ${ }^{1} \mathrm{H}-\mathrm{NMR},{ }^{13} \mathrm{C}-\mathrm{NMR}$, and MS) [27].

The aim of the current study was to evaluate antifeedant and toxic effects produced by natural ACG and their derivatives in the biological control of the polyphagous lepidopteran Spodoptera frugiperda. Additionally, the nutritional indices: Consumption Index (CI), Growth (GR), and Efficiency in the Consumption Index (ECI) were also assessed.

\section{Materials and Methods}

\subsection{Extraction and Purification of Natural ACGs}

Methanol seeds extracts were partitioned between chloroform and water. Then, chloroform was evaporated, extracts cromatographed on a silica gel column (chloroform-ethyl acetate-methanol gradient) and column fractions processed on a Beckman C18 HPLC column $(25 \mathrm{~cm} \times 1 \mathrm{~cm}$ i.d., $5 \mu \mathrm{m}$ particle size $)$ to yield pure ACG. Structural characterization was achieved by IR, ${ }^{1} \mathrm{H}-\mathrm{NMR},{ }^{13} \mathrm{C}-\mathrm{NMR}$, and EIMS.

\subsection{ACG Derivatives}

Acetylated analogs (enzymatic acetylation) were obtained by dissolving the ACG in mixture of dichloro-methane $(5 \mathrm{ml})$ and vinyl acetate $(1.2 \mathrm{~mol}$ per $\mathrm{OH}$ group to be acetylated) in a screw cap vial. Then lipase (Candida antarctica B) was added $\left(10 \%-30 \%\right.$ of ACG weight) and vial placed on an orbital shaker $\left(37^{\circ} \mathrm{C}\right.$, 150 - $200 \mathrm{rpm}$ ) until completion of reaction as shown by TLC. Finally, lipase was filtered and washed with dichloro-methane Solvent was removed from the liquid fraction in a rotary vacuum evaporator and aceylated compounds purified by flash column chromatography.

Methoxy methylated ACG derivatives were obtained by reaction with $\mathrm{N}, \mathrm{N}$-diisopropylethylamine and methoxymethyl chloride in dichloromethane under a nitrogen atmosphere. At completion of the reaction (shown by TLC) solvent was removed, residue chromatographed on flash column and chemical structure of products assessed by ${ }^{1} \mathrm{H}-\mathrm{NMR}$ and ${ }^{13} \mathrm{C}-\mathrm{NMR}$ by comparison with ACG precursors.

\subsection{Test Insects: Diet and Formulations}

Spodoptera frugiperda larvae were obtained from our laboratory population. The larval diet was prepared as follows: yeast, $3 \mathrm{~g}$; milled and boiled bean, $250 \mathrm{~g}$; wheat germ, $12.5 \mathrm{~g}$; agar-agar, $12.5 \mathrm{~g}$; ascorbic acid, $1.5 \mathrm{~g}$; methyl p-hydroxybenzoate, $1.5 \mathrm{~g}$; formaldehyde $38 \%$ water solution, $4 \mathrm{ml}$; water, $500 \mathrm{ml}$. Acetone so- 
lutions of natural ACG and derivatives were prepared $\left(100 \mu \mathrm{g} \cdot \mathrm{ml}^{-1}\right)$.

\subsection{No Choice Test}

A portion of larval diet was thoroughly mixed with an acetone ACG solution (or ACG derivative) to leave $100 \mu \mathrm{g}$ of compound per $\mathrm{g}$ of diet (treated) [24] and solvent left to evaporate at room temperature. Another portion was impregnated with acetone and used as control diet. Traces of solvent were removed in a desiccator. Cotton plugged test tubes containing $2^{\text {nd }}$ instar larvae ( 1 per tube) were added with either control or treated diet and kept at $27^{\circ} \mathrm{C}$ and $60 \% \pm 15 \%$ relative humidity. Upon consumption of $50 \%$ of control diet, remaining diets were removed and weighed accurately and feeding ratio was calculated as $\mathrm{FR}_{50}=\mathrm{T} / \mathrm{C}$ [28] ( $\mathrm{T}$ and $\mathrm{C}$ represent weights of diets consumed in the treated and control experiments, respectively).

\subsection{Toxicity Test}

Control and treated diets were placed in cotton plugged test tubes (10 replicates each) with $2^{\text {nd }}$ instar larvae (1 per tube) and kept as mentioned before until the $1^{\text {st }}$ generation of adults emerged. Larval developmental periods as well as mortality rates were recorded for both treatment and control experiments [29].

\subsection{Nutritional Indices}

Homogeneous size $2^{\text {nd }}$ instar larvae were placed in a test tube (1 per tube, 10 replicates) and larval weights measured. Then, accurately weighed portions of either treated or control diet were offered to larvae and kept at $27^{\circ} \mathrm{C}$. Larval weight and diet additions were recorded. Average diet consumption (CI), growth rate (GR) and efficiency in the consumption index (ECI) were calculated, rates expressed as treatment-control ratio and values expressed as $\left(\mathrm{GR}_{\mathrm{T}} / \mathrm{GR}_{\mathrm{C}}\right) 100 \%$ $\left(\mathrm{CI}_{\mathrm{T}} / \mathrm{CI}_{\mathrm{C}}\right) 100 \%$ and $\left(\mathrm{ECI}_{\mathrm{T}} / \mathrm{ECI}_{\mathrm{C}}\right) 100 \%$ in the tables [29]. Control is considered as $100 \%$.

\subsection{Statistical Analysis}

Results are reported as mean $\pm \mathrm{SD}$. The differences in the mean values were evaluated by ANOVA test. The Tukey test was used for pairwise multiple comparisons of groups. In all analyses, $\mathrm{p}<0.05$ indicates significant difference of means [30].

\section{Results}

\subsection{Natural and Derivatives ACGs}

The isolation of ACG from the chloroform sub-extract was guided by the Kedde's reagent (TLC). Repeated chromatographic processes permitted the separation of known ACG. As shown in Figure 1, the following compounds were isolated. Mono-THF ACG: annonacin (1), cis-annonacin (2), cis-annonacin-10-one (3); adjacent bis-THF ACG: asimicin (4), rolliniastatin-2 (5); non 
<smiles>C[C@@H](O)CC1=C[C@@H](C)OC1=O</smiles>
annonacin (1)

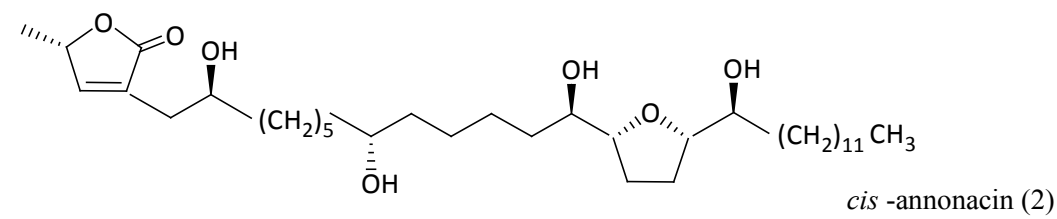

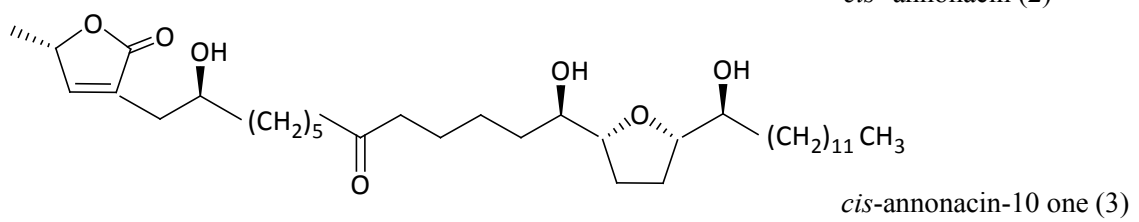

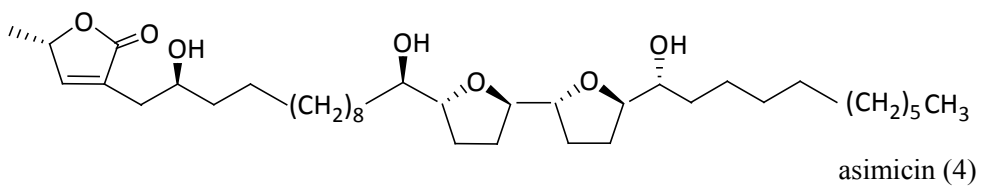

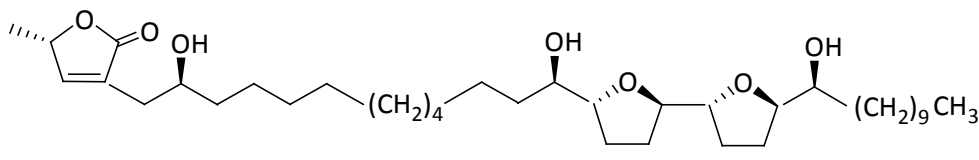
rolliniastatin-2 (5)

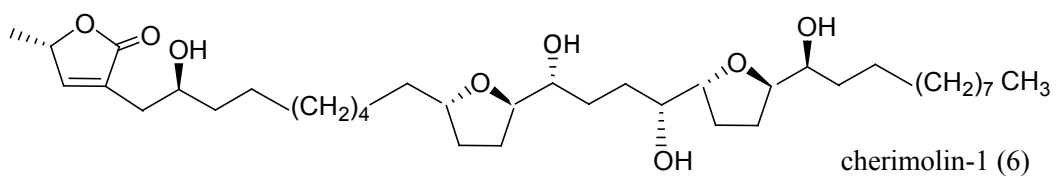

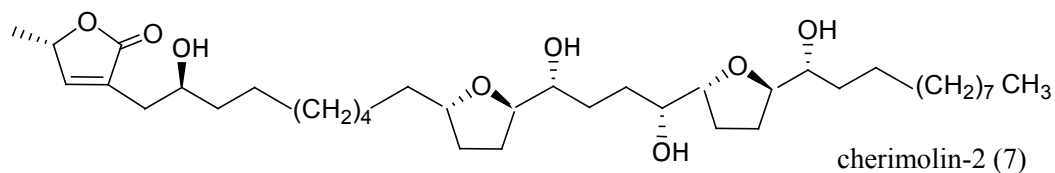<smiles>CCCC1=C[C@@H](C)OC1=O</smiles>

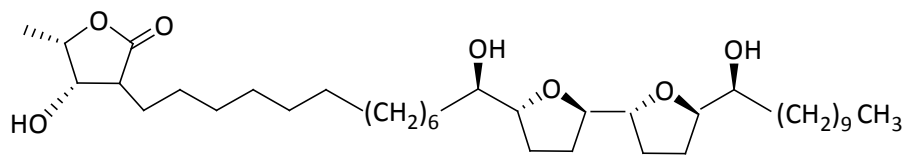
laherradurin (9)

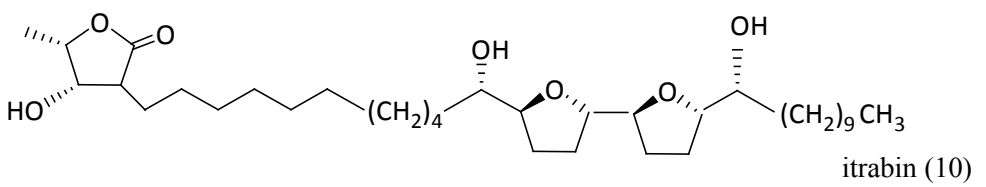

Figure 1. Natural ACG evaluated for their nutritional alterations and toxic effects against Spodoptera frugiperda. 
adjacent bis THF ACG: cherimolin-1 (6), cherimolin-2 (7), almuñequin (8); bis-THF $\beta$-OH ACG: laherradurin (9) and itrabin (10). Derivatives obtained are shown in Figure 2: annonacin (3 OAc) (11) [27], annonacin (4 OAc) (12) [27], asimicin (3 OAc) (13), rolliniastatin-2 (3 OAc) (14) [27], rolliniastatin-2 (MOM) (15), laherradurin (3 OAc) (16) and itrabin (3 OAc) (17) [27].

The identification of chemically acetylated ACGs (13 and 16), both bis-THF, was achieved by comparing spectroscopic data of ${ }^{1} \mathrm{H}-\mathrm{NMR}$ and ${ }^{13} \mathrm{C}-\mathrm{NMR}$ with those of original ACGs samples. In ${ }^{1} \mathrm{H}-\mathrm{NMR}$ it was observed that the signals of the protons corresponding to the hydroxyl-based carbons were displaced to low fields $(\delta 5.0-4.0 \mathrm{ppm})$ and the signals corresponding to the protons of the hydroxyl groups present in the original ACGs disappeared. Likewise, new singlet signals appeared at high fields corresponding to the methyl protons of the acetate groups $(\delta 2.2-2.0 \mathrm{ppm})$.

In ${ }^{13} \mathrm{C}-\mathrm{NMR}$ it was observed that the signals corresponding to the hydroxyl-based carbons move to low fields ( $\delta 75.0-71.0 \mathrm{ppm})$ and new signals appeared to lower fields corresponding to the quaternary carbons of the acetate group ( $\delta 171.0$ - $170.0 \mathrm{ppm}$ ).

The identification of methoxy methylated bis-THF ACG, rolliniastatin-2 (MOM) (15), was achieved by comparing ${ }^{1} \mathrm{H}-\mathrm{NMR}$ and ${ }^{13} \mathrm{C}-\mathrm{NMR}$ spectroscopic data with that of the original ACG. In ${ }^{1} \mathrm{H}-\mathrm{NMR}$ it was observed that the proton signals corresponding to the hydroxyl base carbons that were at $\delta 4.2-4.5 \mathrm{ppm}$ were displaced at $\delta 3.9 \mathrm{ppm}$ and the signals corresponding to the protons of the hydroxyl groups present in the original ACG disappeared. Likewise, new singlet signals appeared between $\delta 3.3-3.5 \mathrm{ppm}$ and $\delta 4.6-4.9 \mathrm{ppm}$, corresponding to the methylic and methylenic protons of the methoxy methyl group respectively.

In ${ }^{13} \mathrm{C}$-NMR it was observed that the signals corresponding to the hydroxyl base carbons that were between $\delta 71.3-74.2 \mathrm{ppm}$, moved to lower fields towards $\delta 79.0-81.8 \mathrm{ppm}$ and new signals appeared at $\delta 55.0-56.0$ and $\delta 96.0-97.0$ ppm, corresponding to the methylic and methylenic carbons of the methoxy methyl group respectively.

\subsection{No Choice Test}

All ACGs evaluated previously had toxic effects on $S$. frugiperda at the dose of $100 \mu \mathrm{g} \cdot \mathrm{g}^{-1}$ or less [24]. As shown in Table 1, the incorporation of $15\left(100 \mu \mathrm{g} \cdot \mathrm{g}^{-1}\right)$ into the artificial diet of $S$. frugiperda displayed the strongest antifeedant effects $\left(\mathrm{FR}_{50}\right)$ followed by 14 causing a marked decrease in larval growth. Antifeedant action of remaining ACG and derivatives was negligible under experimental conditions (Table 1).

\subsection{Toxicity of Natural and Derivatives ACGs}

As shown in Table 1, natural ACG containing adjacent bis-THF groups were more active than those with non-adjacent groups. Moreover, compounds with a single THF group were also less active, except for compound 2 . The structural 


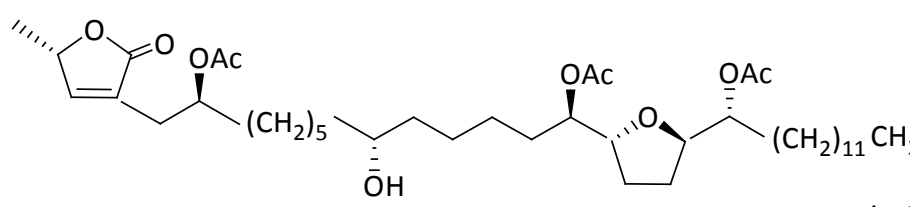
annonacin (3OAc) (11)<smiles>CCCCCC(C)OC(C)CC1=C[C@@H](C)OC1=O</smiles><smiles>CCCCCC[C@H](OC(C)=O)[C@H]1CC[C@H]([C@H]2CC[C@H](C(C)OC(C)=O)O2)O1</smiles>

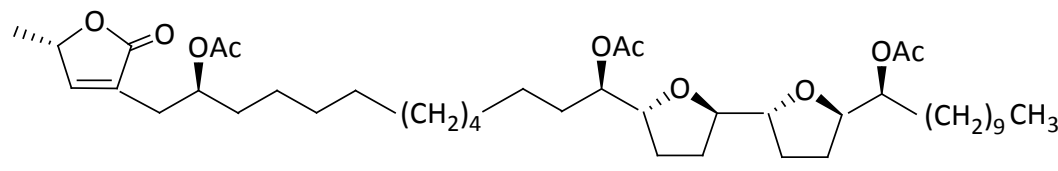
rolliniastatin-2 (3OAc) (14)<smiles>CCCCCCC(CC1=C[C@@H](C)OC1=O)O[C@H](CCCCCC)OC</smiles>
rolliniastatin-2 (MOM) (15)

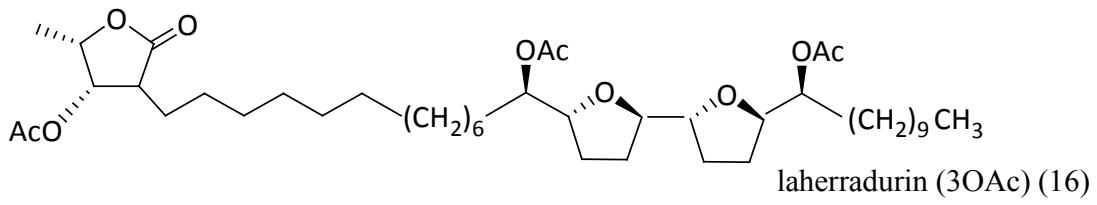

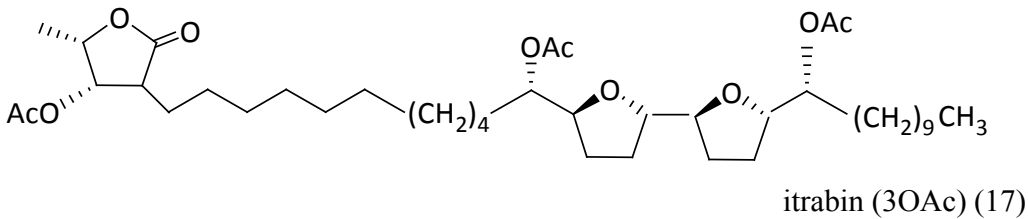

Figure 2. Structurally modified ACGs: acetylated and methoxy methylated derivatives evaluated for their nutritional alterations and toxic effects against Spodoptera frugiperda.

characteristics of the lactonic group also seem to be of importance. Adjacent bis-THF ACG with $\beta$-hydroxylated lactone groups had less activity than those with unsaturated lactone groups.

The natural acetogenin rolliniastatin-2 (100 $\mu \mathrm{g} \cdot \mathrm{g}^{-1}$ of diet $)$ produced the most important toxic action causing $100 \%$ mortality of early instar larvae.

Acetylation and methoxy-methylation of ACG reduced their toxicity (Table 1) and caused malformations and size decrease in surviving adults (see Figure $3(\mathrm{~A})-(\mathrm{C}))$ that led them to death before laying eggs. 
Table 1. Antifeedant and toxic effects of natural and derivatized ACG on Spodoptera frugiperda.

\begin{tabular}{|c|c|c|c|c|}
\hline $\mathrm{COMPOUNDS}^{\dagger}$ & $\mathrm{FR}_{50}{ }^{\dagger \dagger}$ & $\begin{array}{c}\text { LARVAL } \\
\text { MORTALITY (\%) }\end{array}$ & $\begin{array}{c}\text { PUPAL } \\
\text { MORTALITY (\%) }\end{array}$ & $\begin{array}{l}\text { MALFORMED } \\
\text { ADULTS (\%) }\end{array}$ \\
\hline 1 & $1.15 \pm 0.34$ & 5 & 0 & 95 \\
\hline 2 & $1.02 \pm 0.20$ & 60 & 0 & 40 \\
\hline 3 & $0.98 \pm 0.13$ & 0 & 5 & 95 \\
\hline 4 & $1.02 \pm 0.28$ & 85 & 0 & 15 \\
\hline 5 & $0.99 \pm 0.15$ & 100 & 0 & 0 \\
\hline 6 & $0.88 \pm 0.23$ & 15 & 0 & 85 \\
\hline 7 & $0.97 \pm 0.25$ & 5 & 0 & 95 \\
\hline 8 & $0.89 \pm 0.22$ & 20 & 0 & 80 \\
\hline 9 & $0.81 \pm 0.18$ & 70 & 0 & 30 \\
\hline 10 & $0.99 \pm 0.19$ & 45 & 0 & 55 \\
\hline 11 & $1.13 \pm 0.42$ & 5 & 0 & 95 \\
\hline 12 & $1.13 \pm 0.37$ & 10 & 0 & 90 \\
\hline 13 & $0.97 \pm 0.16$ & 70 & 0 & 30 \\
\hline 14 & $0.68 \pm 0.10$ & 40 & 5 & 55 \\
\hline 15 & $0.58 \pm 0.13$ & 40 & 0 & 60 \\
\hline 16 & $0.93 \pm 0.16$ & 65 & 0 & 35 \\
\hline 17 & $0.94 \pm 0.14$ & 65 & 0 & 35 \\
\hline
\end{tabular}

${ }^{\dagger} 100 \mu \mathrm{g} \cdot \mathrm{g}^{-1}$ of diet. ${ }^{\dagger \dagger}$ Mean \pm SD.

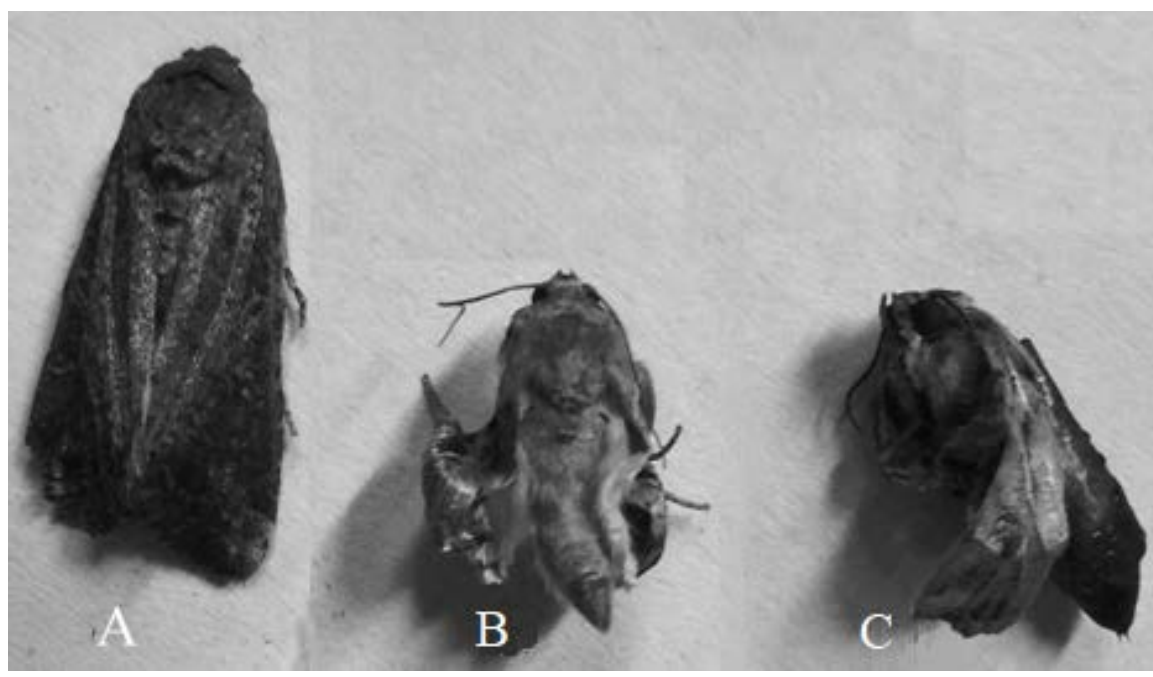

Figure 3. Spodoptera frugiperda: (A) View of untreated adult. (B) and (C) Treated adult showing malformation of wings and legs: laherradurin(3OAc) and itrabin (3 OAc), respectively.

\subsection{Nutritional Indices of Natural and Derivatives ACGs}

Nutritional effects were assessed in order to infer the mechanism of action lead- 
ing to mortality. The decreases in ECI values for natural adjacent bis-THF ACG $(4,9$ and 10) and acetylated bis-THF ACG (13, 14, 16 and 17) are consistent with chronic intoxication leading to death, thus preventing the production of offspring (Table 2). The addition of the methoxy-methylated derivative of rolliniastatin-2 (15) caused less nutritional effects than its acetylated counterpart (14).

\section{Discussion}

Spodoptera frugiperda (J.E. Smith) is a polyphagous lepidopteran commonly called fall armyworm, a major pest in corn fields where it feeds on leaves, tassels and ears of corn [31]. Severe damages are particularly caused during its early larval stages [32]. For this reason, a candidate compound for the control of this pest should preferably produce larval mortality. In agreement with previous work [33], this report highlights rolliniastatin-2 as the most promising compound for Spodoptera frugiperda larvae control. There is however, the need for specific studies on the impact that this compound could have on beneficial species in the agroecosystems. Biological activity of ACG has been little studied in vivo, therefore more tests are required to verify the potential of these compounds in real scenarios.

Table 2. Nutritional effects of natural and derivatized ACG on Spodoptera frugiperda.

\begin{tabular}{|c|c|c|c|}
\hline COMPOUNDS & CIt/CIc (\%) & GRt/GRc (\%) & ECIt/ECIc (\%) \\
\hline 1 & $79 \pm 5^{c, d}$ & $74 \pm 1^{\mathrm{a}, \mathrm{b}}$ & $94 \pm 18^{\mathrm{a}, \mathrm{b}, \mathrm{c}}$ \\
\hline 2 & $89 \pm 7^{\mathrm{a}, \mathrm{b}}$ & $44 \pm 14^{\mathrm{d}, \mathrm{e}}$ & $49 \pm 13^{\mathrm{f}}$ \\
\hline 3 & $77 \pm 8 \mathrm{~d}$ & $58 \pm 14^{\mathrm{c,d}}$ & $74 \pm 13^{\mathrm{d}, \mathrm{e}}$ \\
\hline 4 & $58 \pm 4^{\mathrm{e}}$ & $27 \pm 6^{\mathrm{e}, \mathrm{f}}$ & $46 \pm 7^{\mathrm{f}}$ \\
\hline 5 & $\mathrm{~N} / \mathrm{D}$ & $\mathrm{N} / \mathrm{D}$ & $\mathrm{N} / \mathrm{D}$ \\
\hline 6 & $94 \pm 6^{\mathrm{a}}$ & $72 \pm 12^{\mathrm{a}, \mathrm{b}, \mathrm{c}}$ & $78 \pm 12^{\mathrm{c}, \mathrm{d}}$ \\
\hline 7 & $90 \pm 6^{\mathrm{a}, \mathrm{b}}$ & $75 \pm 14^{\mathrm{a}, \mathrm{b}}$ & $84 \pm 15^{\mathrm{b}, \mathrm{c}, \mathrm{d}}$ \\
\hline 8 & $86 \pm 6^{\mathrm{a}, \mathrm{b}, \mathrm{c}}$ & $59 \pm 16^{\mathrm{b}, c, \mathrm{~d}}$ & $69 \pm 15^{\mathrm{d}, \mathrm{e}}$ \\
\hline 9 & $45 \pm 4^{\mathrm{f}}$ & $4 \pm 2^{\mathrm{g}}$ & $8 \pm 4^{\mathrm{g}}$ \\
\hline 10 & $48 \pm 2^{\mathrm{f}}$ & $11 \pm 2^{\mathrm{f}, \mathrm{g}}$ & $23 \pm 4^{g}$ \\
\hline 11 & $83 \pm 6^{b, c, d}$ & $87 \pm 20^{\mathrm{a}}$ & $104 \pm 20^{\mathrm{a}}$ \\
\hline 12 & $83 \pm 5^{\mathrm{b}, \mathrm{c}, \mathrm{d}}$ & $85 \pm 20^{\mathrm{a}}$ & $102 \pm 20^{\mathrm{a}}$ \\
\hline 13 & $42 \pm 5^{\mathrm{f}}$ & $4 \pm 1^{g}$ & $8 \pm 3^{g}$ \\
\hline 14 & $49 \pm 14^{\mathrm{e}, \mathrm{f}}$ & $27 \pm 9^{\mathrm{e}, \mathrm{f}}$ & $55 \pm 12^{\mathrm{e}, \mathrm{f}}$ \\
\hline 15 & $77 \pm 11^{\mathrm{d}}$ & $76 \pm 15^{\mathrm{a}, \mathrm{b}}$ & $99 \pm 21^{\mathrm{a}, \mathrm{b}}$ \\
\hline 16 & $40 \pm 3^{\mathrm{f}}$ & $3 \pm 1^{g}$ & $7 \pm 2^{g}$ \\
\hline 17 & $47 \pm 4^{\mathrm{f}}$ & $9 \pm 4^{\mathrm{f}, \mathrm{g}}$ & $20 \pm 8^{g}$ \\
\hline
\end{tabular}

Numbers in columns represent Mean \pm SD. Means within a column followed by same letter are not significantly different ( $\mathrm{p}<0.05$, Tukey multiple range test). N/D: Not determined (Mortality at early instars). 
It could be inferred that there is a relationship between the number and arrangement of THF groups, the chemical nature of the terminal lactonic groups and the biological activity of ACG. Adjacent bis THF arrangement seems to achieve the most insecticidal action.

Moreover, it has been suggested that the hydroxyl groups flanking THF are of great influence on biological activity. This becomes clear when we observe how the toxicity of these compounds decreases when these groups are blocked by acetylation or methoxy-methylation reactions [24]. The natural ACGs were the most promising compounds for $S$. frugiperda larvae control

\section{Acknowledgements}

This study was funded by the Consejo Nacional de Investigaciones Científicas y Técnicas and Consejo de Investigaciones de la Universidad Nacional de Tucumán, Argentina.

\section{References}

[1] Clemente, S., Mareggiani, G., Broussalis, A., Martino, V. and Ferraro, G. (2003) Insecticidal Effects of Lamiaceae Species against Stored Products Insects. Boletin Sanidad Vegetal, Plagas, 29, 1-8.

[2] Silva, G., Lagunes, A., Rodríguez, J. and Rodríguez, D. (2002) Insecticidas vegetales: una vieja y nueva alternativa para el manejo de plagas. Manejo Integrado de Plagas y Agroecología, 66, 4-12.

[3] Long, Z., Hock, S. and Hung, S. (2006) Screening of Chinese Medicinal Herbs for Bioactivity against Sitophilus zeamais Motschulsky and Tribolium castaneum (Herbst). Journal Stored Products Research, 43, 290-296.

[4] Isman, M.B. (2006) Botanical Insecticides, Deterrents and Repellents in Modern Agriculture and an Increasingly Regulated World. Annual Review Entomology, 51, 45-66. https://doi.org/10.1146/annurev.ento.51.110104.151146

[5] García-Mateos, R., Pérez, P.R., Rodríguez, H.C. and Soto, H.M. (2004) Toxicidad de alcaloides de Eythrinaamericana en larvas de mosquito Culexquinquefasciatus. Revista Fitotecnia Mexicana, 27, 297-303.

[6] Álvarez Colom, O., Neske, A., Popich, S. and Bardón, A. (2007) Toxic Effects of Annonaceousacetogenins from Annonacherimolia (Magnoliales: Annonaceae) on Spodoptera frugiperda (Lepidoptera: Noctuidae). Journal Pest Science, 80, 63-67. https://doi.org/10.1007/s10340-006-0149-2

[7] Salvadores, U.Y., Silva, A.G., Tapia, V.M. and Hepp, G.R. (2007) Polvos de especias aromáticas para el control del gorgojo del maíz, Sitophilus zeamais Motschulsky, en trigo almacenado. Agricultura técnica (Chile), 67, 147-154.

https://doi.org/10.4067/S0365-28072007000200004

[8] Chandra, B., Kumar, P. and Matiur, M. (2008) Aphidicidal Activity of Some Indigenous Plant Extracts against Bean Aphid Aphis craccivora Koch (Homoptera:Aphididae). Journal Pest Science, 81, 153-159.

https://doi.org/10.1007/s10340-008-0200-6

[9] Cavalcante, G., Carrano, A. and Dias, S. (2006) Potencialidade inseticida de extratos aquosos de esencias florestais sobre mosca branca. Pesquisa Agropecuaria Brasileira, 41, 9-14. https://doi.org/10.1590/S0100-204X2006000100002

[10] Celis, A., Mendoza, C., Pachón, M., Cardona, J., Delgado, W. and Cuca, L. (2008) 
Extractos vegetales utilizados como biocontroladores con énfasis en la familia piperácea. Una Revisión. Agronomia Colombiana, 26, 97-106.

[11] Viglianco, A.I., Novo, R., Cragnolini, C. and Nassetta, M. (2006) Actividad biológica de extractos crudos de Larrea divaricata Cav. y Capparisata misquea Kuntze sobre Sitophilus oryzae (L.). Agriscientia, 23, 83-89.

[12] Eriksson, C., Mansson, P., Sjodin, K. and Schlyter, F. (2008) Antifeedants and Feeding Stimulants in Bark Extracts of Ten Woody Non-Host Species of the Pineweevil, Hylobiusabietis. Journal Chemical Ecology, 34, 1290-1297. https://doi.org/10.1007/s10886-008-9525-0

[13] Wheeler, D. and Isman, M. (2001) Antifeedant and Toxicactivity of Trichilia americana Extract against the Larvae of Spodoptera litura. Entomologia Experimentalis et Applicata, 98, 9-16. https://doi.org/10.1046/j.1570-7458.2001.00751.x

[14] Koul, O. (2004) Biological Activity of Volatile D-n-Propyl Difulside from Seeds of Neem, Azadirachta indica (Meliaceae), to Two Species of Stored Grain Pests, Sitophilus oryzae (L.) and Tribolium oryzae (Herbst). Journal Economic Entomology, 97, 1142-1147. https://doi.org/10.1093/jee/97.3.1142

[15] Banchio, E., Valladares, G., Defago, M., Palacios, S. and Carpinella, C. (2003) Effects of Melia azedarach (Meliaceae) Fruit Extracts on the Leaf Miner Lirio mizahui dobrensis (Diptera, Agromyzidae): Assessment in Laboratory and Field Experiments. Annals Applied Biology, 143, 187-193. https://doi.org/10.1111/j.1744-7348.2003.tb00285.x

[16] Peterson, C. and Coats, J. (2001) Insect Repellents. Past, Present and Future. Pesticide Outlook, 12, 154-158. https://doi.org/10.1039/b106296b

[17] Ocampo, D. and Ocampo, R. (2006) Bioactividad de la familia Annonaceae. Revista Universidad de Caldas, 135-155.

[18] Castillo-Sánchez, L.E., Jiménez-Osornio, J.J. and Delgado-Herrera, M.A. (2010) Secondary Metabolites of the Annonaceae, Solanaceae and Meliaceae Families used as Biological Control of Insects. Tropical and Subtropical Agroecosystems, 12, 445-462.

[19] Alali, F., Liu, X. and Mc Laughlin, J. (1999) Annonaceous Acetogenins: Recent Progress. Journal Natural Products, 62, 504-540. https://doi.org/10.1021/np980406d

[20] Leatemia, J. and Isman, M. (2004) Efficacy of Crude Seed Extracts of Annona squamosa against Diamond Back Moth, Plutella xylostella L. in the Greenhouse. International Journal Pest Management, 50, 129-133. https://doi.org/10.1080/096708704100001691821

[21] Guadaño, A., Gutiérrez, C., De La Peña, E., Cortes, D. and González-Coloma, A. (2000) Insecticidal and Mutagenic Evaluation of Two Annonaceous Acetogenins. Journal Natural Products, 63, 773-776. https://doi.org/10.1021/np990328+

[22] Domínguez-Martínez, V., Martínez-Vázquez, M., Collar-Gómez, E., Atzin-García, J. and Chimalpopoca, F.L. (2003) Pupicidal Activity of Annonacin for Aedes aegypti (L.) (Diptera: Culicidae). Folia Entomológica Mexicana, 42, 349-358.

[23] Bobadilla, M., Zavala, F., Sisniegas, M., Zavaleta, G., Mostacero, J. and Taramona, L. (2005) Evaluación larvicida de suspensiones acuosas de Annona muricata Linnaeus (guanábana) sobre Aedes aegypti Linnaeus (Diptera, Culicidae). Revista Peruana de Biología, 12, 15-152.

[24] Di Toto Blessing, L., Álvarez Colom, O., Popich, S., Neske, A. and Bardón, A. (2010) Antifeedant and Toxic Effects of Acetogenins from Annona montana on Spodoptera frugiperda. Journal Pest Science, 83, 307-310.

https://doi.org/10.1007/s10340-010-0299-0 
[25] Álvarez Colom, O., Neske, A., Barrachina, I., Ayala Mingol, I., Moya Sanz, P. and Bardón, A. (2008) Toxic Effects of Annonaceous Acetogenins on Oncopeltus fasciatus. Journal Pest Science, 81, 85-89. https://doi.org/10.1007/s10340-007-0189-2

[26] Álvarez Colom, O., Salvatore, A., Willink, E., Ordóñez, R., Isla, M.I., Neske, A. and Bardón, A. (2010) Insecticidal, Mutagenic and Genotoxic Evaluation of Annonaceous Acetogenins. Natural Product Communication, 5, 391-394.

[27] Di Toto Blessing, L., Budeguer, F., Ramos, J., Diaz, S., Bardón, A., Brovetto, M., Seoane, G. and Neske, A. (2015) Structural Factors of Annonaceous Acetogenins and Their Semisynthetic Analogues Related with Their Toxicity on Spodoptera frugiperda. Journal of Agricultural Chemistry and Environment, 4, 56-61. https://doi.org/10.4236/jacen.2015.42006

[28] Cole, M.D. (1994) Key Antifungal, Antibacterial and Anti-Insect Assays: A Critical Review. Biochemical Systematics and Ecology, 22, 837-856.

https://doi.org/10.1016/0305-1978(94)90089-2

[29] Villafañe, E., Tolosa, D., Bardón, A. and Neske, A. (2011) Toxic Effects of Citrus aurantium and $C$. lemon Essential Oils on Spodoptera frugiperda (Lepidoptera: Noctuidae). Natural Product Communication, 6, 1389-1392.

[30] Statistix 7.1 (2000) Analytical Software.

[31] Marenco, R.J., Foster, R.E. and Sanchez, C.A. (1992) Sweet Corn Response to Fall Armyworm (Lepidoptera: Noctuidae). Damage during Vegetative Growth. Journal Economic Entomology, 85, 1285-1292. https://doi.org/10.1093/jee/85.4.1285

[32] Murúa, M.G. and Virla, E. (2004) Population Parameters of Spodoptera frugiperda (Smith) (Lep. Noctuidae). Fed on Corn and Two Predominant Grasess in Tucumán (Argentina). Acta Zoológica Mexicana, 20, 199-210.

[33] Tolosa, D., Alvarez Cólom, O., Bardón, A. and Neske, A. (2012) Insecticidal Effects of Acetogenins from Rollinia occidentalis Seed Extract. Natural Product Communication, 12, 1645-1646. 